\title{
Pulmapäeva külastuspaigad Narvas: pulmasõidu kujunemise ajaloost
}

\author{
Jelena Nõmm \\ Tartu Ülikooli Narva Kolledži vene kultuuri lektor \\ Jelena.Nomm@ut.ee \\ Olga Burdakova \\ Tartu Ülikooli Narva Kolledži vene keele dotsent \\ Olga.Burdakova@ut.ee
}

\begin{abstract}
Teesid: Artiklis käsitletakse pulmasõitu kui vene pulmakombestiku püsivat komponenti nõukoguliku ajastu kultuuriruumis. Antakse ülevaade selle rituaalse tava sündimisloost, tutvustatakse uurijate erinevaid versioone, kuidas kujunes nõukogulik komme külastada abielu sõlmimise päeval noorpaari ja pulmakülalistega teatud kohti. Fookuses on 1960. aastatel tekkima hakanud Narva pulma-marsruudi peatuspaigad. Sellel perioodil kinnistus pulmamarsruut - linnast eeslinna (Narva-Jõesuu). Artiklis vaadeldakse pulmamarsruudi kolme peatuspaika: Lenini monument Peetri väljakul, ringristmik linna keskel, "Šiškini mänd" (Narva-Jõesuu). Kaks viimast on säilitanud oma positsiooni ka tänapäeva pulma-marsruudis. Pulmapäeva külastuspaikade ümber kujuneb rituaalne kultuur ja kohalik folkloor.
\end{abstract}

Märksõnad: pulmamarsruut Narvas, pulmapäeva peatuspaigad, tänapäeva folkloor, vene pulmakombestik

\section{Sissejuhatus}

Rahvalike (eelkõige külakultuuri puudutavate ja talupoeglike) pulmakommete ja rituaalide uurimine on üks vene folkloristide ja etnograafide traditsioonilisi valdkondi (Puškarjova \& Šmeljova 1959; Tšistov \& Berštam 1978 jt). 20. sajandi teisest poolest kuni 21. sajandi alguseni on tehtud katseid rekonstrueerida ja kirjeldada kaasaegseid pulmatavandeid linnas. Retrospektiivses ja võrdlevas võtmes on kirjeldatud küla- ja linnaelanike pulmakombeid 11.-20. sajandini (Timofejeva 2004); 16. sajandi linna pulmatavandeid (Rabinoviť̌ 1978); kaupmeeste pulmatraditsioone Siberi linnades 18. sajandist 19. sajandi keskpaigani (Kuzmina 2010) ja pulmatavandite arengut Venemaa keskvööndi väikestes ja keskmistes linnades 19. sajandi keskelt kuni 20. sajandi 70. aastateni 
(Žirnova 1980). Ka Eesti pulmakombestiku uurimisel on kauaaegne ajalugu. Uurijate vaateväljas on olnud küsimused traditsioonilisest pulmakombestikust, aga ka uute pulmatavandite tekkimine Eesti NSVs 20. sajandi teisel poolel ning tänapäeva eesti pulmakommete eripärad (Kalits 1981; Boode 2004; Kalits 1988; Tedre 1973; Toomistu 2005).

Viimasel ajal on tehtud katseid kirjeldada sellist kaasaegse linnakultuuri pulmakombestiku komponenti nagu pulmapäeva külastuspaigad (Gromov 2012) ning modelleerida pulmafotode koodi ja kaanonit (Boitsova 2007).

Venemaa ja endiste nõukogude liiduvabariikide (sealhulgas Eesti) territooriumil on pulmamarsruut või noorpaari sõit mööda vaatamisväärseid paiku üks vene linna pulmakombestiku toimiv osa.

Pärast abielu pidulikku registreerimist suundub noorpaar sõprade ja sugulastega või ka ilma nendeta oma sõiduvahenditel (autoga) või spetsiaalselt tellitud bussiga sõidule linna piirides või selle ümbruses. Marsruut on kas ette planeeritud või kujuneb stiihiliselt. Linna pulmamarsruut haarab endasse üsna püsiva, standarditele ja stereotüüpidele vastava valiku objektidest linnas ja linnaümbruse maastikel: mälestusmärgid, sillad, pargid, loodusobjektid (veejoad, puud) jms. Pulmakorteež peatub iga sellise objekti juures, noorpaar ja külalised väljuvad sõidukist ning sooritavad teatud rituaalseid või mängulisi toiminguid. Pulmasõidul on mitu funktsiooni. Esiteks on sellel demonstratiivne iseloom: autod, mis on ehitud lintide ja lilledega, joonduvad üksteise järel kolonni ning sõidavad signaali andes (tuututamine) perekonnaseisuametist mööda linna peatänavaid, teavitades linnarahvast pidulikust sündmusest ja pereseisu muutumisest. Teiseks on pulmasõidul meelelahutuslik-lõbustuslik iseloom: see täidab aja, mis jääb abielu ametliku sõlmimise ja pulmapeo vahele. Kolmandaks on sellel mälufunktsioon: pulmasõitu saadab fotode tegemine, mis jäädvustab pere ajaloo olulise sündmuse detailid. Neljandaks on sellel rituaalne funktsioon, sest teatud kombetalitused, mida sooritatakse objektide juures, pärinevad arhailisest kultuurist ning lubavad paigutada tänapäeva pulmasõidu mineviku pulmatraditsiooni konteksti. Lõpuks on teatud paikade külastamise eesmärgiks pulmapäeval ka linlaste kohaliku identiteedi toetamine: noorpaar kinnitab traditsiooniliste linnakommete täitmisega oma seost elukohaga.

Käesolevas artiklis on tehtud katse rekonstrueerida Narva pulmasõidu tekkimise ajalugu, kirjeldada kõige varasemaid kohti, mis arvati pulmapäeva külastuspaikade hulka ja selgitada, millised neist on säilitanud püsiva koha pulmamarsruudis, tuua välja põhjused, mille järgi objektid arvatakse marsruudi sisse ning mõtestada mõningaid pulmapäeva peatuspaikadega seotud kombeid ja rituaale. Külastatud kohtade analüüsimisel on tähelepanu keskmes kohalik kultuurimälu ja Narva linna folkloor. Ainest on iseloomustatud lähtudes vene nüüdisfolkloristika terminitest, $n t$ linna oludes dünaamiliselt kujuneva 
narratiivse folkloori vastena post-folkloor ${ }^{1}$ (vt Nekljudov 2013a; Nekljudov 2013b).

\section{Allikad ja uurimismeetodid}

Artikli aluseks on 14 intervjuu analüüs. Need tehti narvalastega, kes rääkisid 2014. aastal oma pulmadest ja nendest pulmadest, kus nad viibisid külalisena. Poolstruktureeritud intervjuu toimus vabas vormis. Meid huvitas, kas pärast abielu sõlmimist toimus pulmasõit ning kas selle marsruut oli ette läbi mõeldud või toimus kõik spontaanselt. Palusime vastajal mälu järgi taastada marsruut ja jutustada, millised toimingud leidsid aset iga külastuspaiga juures. Intervjuu käigus küsisime iga vastaja arvamust selle kohta, kui kohustuslik või vaba oli iga pulmasõidu vältel külastatud paikade valik. Narvakate refleksioon aitab mõista põhjuseid, miks teatud paik kas arvati või ei arvatud marsruudi sisse. Lähtusime eeldusest, et paiga püsivus marsruudis võib olla seotud sellega, kuivõrd on ta põimunud linna mitte-ametliku ajalooga. Objekt sulandub linna ajalukku laiahaardeliste narratiivistruktuuride kaudu, seetõttu küsisime intervjuudes ka seda, millised kuulujutud, kõmu või lood on seotud pulmasõidu marsruudi vastava paigaga. Kui omavahel sugulussidemetes mitteolevate inimeste intervjuudes kordusid teatud narratiivid ning kui neil oli püsiv motiivikogum, tunnistasime need narratiivid tänapäeva linnafolkloori tüüpilisteks koostisosadeks.

Intervjuud erinevas eas narvalastega andsid võimaluse koostada nimekiri paikadest, mis kuulusid erinevatel aegadel pulmamarsruuti, samuti nendega seotud rituaalsetest tegevustest, kuid ei võimaldanud piiritleda tüüpilisi ja individuaalseid marsruute. Selleks et tuua välja standardne ja stereotüüpne kiht individuaalse taustal, tuli lisada linlaste massilise anketeerimise andmed. Ankeedi aluseks sai nimekiri 15 paigast, mis kordusid erinevate vastajate lugudes. Selles küsiti, millal abielu sõlmiti, millises perekonnaseisuosakonnas see toimus ning kas pärast seda leidis aset pulmasõit (ja kui mitte, siis miks). Vastajad, kes külastasid teatud paiku oma pulmapäeval, pidid märkima nimekirjas ära need paigad ja tuletama meelde nende järjekorra marsruudis. Järgnevalt valisid vastajad võimalike rituaalsete tegevuste hulgast välja toimingud, mida nende pulmasõidul nimetatud objektide juures sooritati või ei sooritatud. Nii marsruudi peatuspaikade kui ka rituaalsete tegevuste nimekirja võis täiendada, ankeet võimaldas vastajal taastada reaalne marsruut isegi siis, kui meie koostatud nimekirjas neid külastuskohti märgitud ei olnud.

Anketeerimine toimus aastail 2014-2015. Saime kokku 119 ankeeti, mis lubasid rekonstrueerida vastanute pulmasõitude marsruudid. Välitöö käigus 
oli meile põhimõtteliselt oluline kaasata linna elanikkonna erinevatesse sotsiaalsetesse kihtidesse kuuluvaid eri põlvkondade esindajaid. Seetõttu küsisime vastajailt ka eluloolisi andmeid.

Narva pulmasõitude uurimise lisaallikatena kasutasime kuut intervjuud, mis tehti 2011. aastal Tartu Ülikooli Narva Kolledži antropoloogilise ekspeditsiooni käigus. Selle algatajaks oli Peterburi Riiklik Ülikool, kes suunas Narva rühma uurijaid ja gümnasiste kohaliku materjali kogumiseks. Selleks, et täpsustada teatud detaile, viisime aastail 2014-2016 täiendavalt läbi kaks intervjuud - mälestusmärkide autorite ja restauraatoritega.

Praegu koosneb meie arhiiv ajavahemikul 1955-2015 Narvas toimunud 146 pulma andmestikust ja lugudest.

\section{Pulmasõit kui pulmakombestiku element}

Pulmarongi koostamise traditsioon erinevatest pulma ametimeestest oli 10.17. sajandini üks vana-vene ja vene rahvusliku pulmakombestiku kohustuslik element (Timofejeva 2004: 43). See säilis linna, küla ja aadliolustikus ${ }^{2} 18$. ja 19. sajandil (Timofejeva 2004: 65-67) ning 20. sajandi alguses (Timofejeva 2004: 83). Uurijad märgivad, et vaatamata pulmakombestiku paljudele kohalikele variantidele on pulmarong vene pulmakombestiku iseloomulik ühisosa (Timofejeva 2004: 83).

19. sajandi ja 20. sajandi alguse külaolustikus kogunes saajarahvas (peigmehe sugulased) pulmapäeval peigmehe koju ja sõitis "olenevalt aastaajast, kas saanidel või vankritel" (Timofejeva 2004: 74) pruudi koju. Seejärel sõitsid pruut ja peigmees "enamasti [---] ühes pulmarongis, kuid erinevatel vankritel" (Žirnova 1980: 51) kirikusse ja pärast laulatust edasi peigmehe majja. Teel kirikust "võžlivets ${ }^{3}$ [---] hoidis korda ja rahu, püüdis jälgida, et kas pole teel takistusi. Kui tee peale jäi kõrts, siis jäi rong tingimata seisma ning tõsjatskii ${ }^{4}$ ostis viina ja kostitas kõiki, sealhulgas ka noorpaari” (Timofejeva 2004: 77). Nii näeme, et külakultuuri rituaalses pulmarongis (sisuliselt tee kirikusse ja kirikust tagasi) puudus sõit läbi külastuspaikade.

19. sajandi lõpu ja 20. sajandi alguse linnakultuuris "sõitsid peigmees ja pruut kirikusse erinevate pulmarongidega. [---] Pruut sõitis kalessis või tõllas kosjamoori ehk tädi saatel ning nende järel tulid vankris tüdrukud-"saatjad", nende järel peiupoisid ja küünlaga poisike. [---] Peigmees oma peiupoiste ja sõpradega sõitsid varem kohale ja ootasid pruuti kiriku juures" (Žirnova 1980: 51). Laulatuse ajal ehiti pulmarong lilledega, aga teel kirikust "sõitis pulmarong kõigepealt mööda kesktänavaid, siis tegi linnale ringi ning alles siis suundus maja poole, kus toimus ball" (Žirnova 1980: 53). Selline traditsioon "sõita 
pulmarongiga ümber linna" (Timofejeva 2004: 89-90) oli üldlinnalik (ja omane kõikidele seisustele). Seda Venemaa impeeriumi linnades levinud traditsiooni peab Galina Žirnova nõukogude pulmasõitude eelkäijaks.

Teiste uurijate arvates on nõukogude komme - mälestusväärsete paikade külastamine pärast abielu registreerimist perekonnaseisuametis - tekkinud üsna hiljuti, 1960. aastate teisel poolel (Gromov 2012).

Paljud uurijad seostavad selle kombe päevakajaliseks muutumist toonase pulmatseremoonia arenguga tervikuna. Küsimus uue nõukogude tavandi tekitamisest tõusis sõjajärgsetel aastatel esmalt päevakorda 1950. aastate lõpus (Hruštšovi ajastu), mil ajakirjanduses hargnes diskussioon sellest, kas "seda on üldse vaja (nõukogude tavand - J. N., O. B.), ja kui on vaja, siis milline see peaks olema" (Smolkin-Rotrok 2012: 448). Diskussiooni tulemusena algas töö uue pulmakombestiku loomiseks kohtadel. 1960. aastate alguseks oli Moskvas, Leningradis, Vene NFSV erinevates piirkondades ja oblastites, samuti NSVL vabariikides, sh ka Eestis olemas uute pulmakommete ja -rituaalide juurutamise positiivne kogemus.

Seejuures pöörati suurt tähelepanu abielu ametliku sõlmimise pidulikule poolele (ühiskondlike ja ametialaste organisatsioonide osalusel), pulmapeo ja pulmalaua korraldamisele. Eesti linnades loodi ilmaliku tavandiga tegelevad komisjonid, kuhu kuulusid parteikomitee, linnade ja rajoonide täitevkomiteede, komsomoliorganisatsioonide, perekonnaseisuosakondade, ajalehetoimetuste, muuseumite, ülikooli jne esindajad. Nõukogude pulmatavade loomiseks said komisjonide liikmed tuge rahvakultuurist ja need loodi vastukaaluks kiriklikule pulmatavandile, kasutusele võeti mitmeid arhailise pulmatavandi fragmente. Erinevate komisjonide tööst saadud positiivne kogemus leidis 1950.-1960. aastatel Eestis mõtestamist ja populariseerimist soovitusliku iseloomuga temaatilistes brošüürides (vt nt Nõuandeid 1959; Tähistagem 1960; Kaunilt 1965).

Positiivne kogemus uue pulmatavandi loomisel Moskva, Leningradi, Volgogradi, Kemerovo, Krasnodarski, Tšeljabinski, Sverdlovski, Permi, Voroneži oblastis ja Baškiiri autonoomses liiduvabariigis leidis heakskiidu 1960. aastate alguses NLKP Keskkomitee tasemel ja kuulus, vastavalt Vene NFSV Ministrite Nõukogu 1964. aasta 18. veebruari määrusele № 203 ("Uute ilmalike tavandite juurutamine nõukogude inimeste argiellu”) laiale levitamisele. Vene Föderatsiooni Ministrite Nõukogu kohustas autonoomsete vabariikide ministrite nõukogusid ning Vene NSFV piirkondade ja oblastite täitevkomiteesid looma linnades ja asulates ilmalike tavanditega tegelevaid ühiskondlikke komiteesid ja juurutama uue ilmaliku tavandi positiivset kogemust, kaubandusministeeriumit aga organiseerima poode ja osakondi, mis spetsialiseeruksid noorpaarikaupadele (Määrus 1964: 41-45). 
Nii loodi Nõukogude Liidus 1950. aastate lõpus ja 1960. aastatel plaanipäraselt pulmade ilmalik tavand. Sellel taustal on külastamisväärseid paiku väisava pulmasõidu tekkimine üsna seaduspärane. Spetsiaalsed pulmapeo korraldamist käsitlevad brošüürid soovitasid sündmuse pidulikkuse võimendamiseks kasutada pulmapäeval ilusat autot ja tuletasid korraldajatele meelde pulmaronge rahvakultuurist kui pulmarituaali traditsioonilist elementi (Nõuandeid 1959: 13; Tähistagem 1960: 30). Bussi- ja taksopargid olid kohustatud andma noorpaari käsutusse ilusa auto perekonnaseisuosakonda sõitmiseks ja sealt naasmiseks (Nõuandeid 1959: 12; Tähistagem 1960: 30). Seejuures märkisid brošüüri autorid, et linnas ei ole sobiv tekitada takistusi noorpaari autoteele (nagu see oli kombeks pulmarongi jälitamisel külades) (Tähistagem 1960: 30), ent soovitasid siiski ette valmistada ülesandeid noorpaarile perekonnaseisuosakonnast väljumisel või pulmapeo kohta saabumisel. Brošüüris "Kaunilt, meeldejäävalt” (Kaunilt 1965) soovitati näiteks hoida varuks pulmategevus, mis kujunes Viljandi rajoonis (Eesti): pärast abielu registreerimist sõitis noorpaar pool tundi autoga mööda linna, külalised aga läksid samal ajal jalgsi perekonnaseisuosakonnast banketi toimumise kohta ja valmistasid seal ette ülesanded vastabiellunutele (Kaunilt 1965: 51). Aegapidi kujunes ilmselt komme kasutada pulmarongides autosid. Samas ei leidu kättesaadavates allikates soovitusi monumentide või tähelepanuväärsete paikade külastamise kohta. Tõenäoliselt tekkis see komme spontaanselt, pulmaliste initsiatiivil.

\section{Narva pulmamarsruudi kujunemise ajalugu}

Linnamaastiku stiihiline kasutamine hakkas Narva pulmakombestikus kujunema nõukogude perioodil (1960. aastatel) ja seetõttu on selles väga palju ka vene (nõukogude) linnarituaalide traditsioonis ilmnevaid jooni (vrd Gromov 2012).

Vastajad märgivad, et pulmamarsruudi valimine toimus pulmapäeval tihti spontaanselt. Vrd: erinevatesse põlvkondadesse kuuluvate narvalaste vastused küsimusele selle kohta, kas nad planeerisid pulmamarsruuti ette:

NK: Tegelikult me ei mõtelnud, ei planeerinud (EN 14-02).

OO: Noh, ma ei tea, mulle tundub isegi, noh, et kui kord juba pulm on, siis see on niigi arusaadav, et ... Noh, kui seda nü̈̈d arutama hakata, et kui ehk mingid uued kohad. Muidu on niigi selge, kuhu need pulmad ikka sõidavad. Kogu aeg on üks ja seesama marsruut (EN 14-01).

On iseloomulik, et selles spontaansuses peegeldub standard, linlase teadvusesse programmeeritud kaanon. Andmepangas on kirjeldusi kaanonist kõrvale- 
kaldumisest, samas rõhutavad vastajad selliste kõrvalekaldumiste teadlikkust, soovi koostada oma pulma marsruut vastupidiselt väljakujunenud kaanonile.

1960. aastatel oli Narva pulmamarsruudis kolm traditsioonilist külastuskohta: ideoloogiline objekt linna peaväljakul - Lenini monument, ringristmik linna põhimagistraalide ristumise kohas, mida linlased kutsusid Ringiks ning üks looduslik objekt, mis asus $21 \mathrm{~km}$ kaugusel linnast - "Šiškini mänd".

1970. aastatel lisandusid pulmapäeva külastuskohtade hulka kolm objekti: “Tank”, "Kolm tääki” ja Mereküla-dessandi mälestusmärk. Kõik need sõjakuulsusele pühendatud mälestusmärgid paigutati Narva ümbrusesse just sel ajal.

1980.-1990. aastatel lülitati Narva traditsioonilisse pulmamarsruuti ka loodusobjektid: Lepaauk Narvas, Hele park ja Jõepaadisild, mis asuvad 14 km kaugusel Narvast - Narva-Jõesuu kuurortlinnas. Neil aastatel hakkasid noorpaarid külastama ka Narva arhitektuurimälestusmärke - Narva kindlust ja raekoda.

1990. aastatel kadus pulmasõitude külastuskohtade seast Lenini monument, 2000. aastatel aga sõjamälestusmärk "Kolm tääki".

2000. aastatel lisandusid pulmamarsruutidesse linna keskele püstitatud uued mälestusmärgid "Rootsi lõvi" ja "Pulmapuu". "Rootsi lõvi" on rekonstruktsioon mälestusmärgist, mis tähistab rootslaste võitu Narva lahingus 1700. aastal, "Pulmapuu" püstitati lossiparki 2008. aastal linnavõimude eestvedamisel, see kujutab endast hõbedakarva rauast puud, mille külge noorpaarid saavad abielu sõlmimise päeval kinnitada oma nimedega rauast lehekesi.

Käesolevas artiklis kirjeldatakse Narva pulmamarsruudi kolme objekti Lenini monument Peetri väljakul, ringristmik linna keskel ja Šiškini mänd Narva-Jõesuus - ilmumise ajalugu ja "saatust" kohalikus pulmatraditsioonis.

\section{Narva pulmasõidu kujunemine 1960. aastatel}

\section{Lenini monument}

Esimene objekt narvalaste nõukogudeaegses pulmamarsruudis oli Lenini monument, mis asus graniitjalamil Peetri väljaku põhjapoolses osas (vt foto 1). Mälestusmärk avati 7. novembril 1957. a, selle autorid on skulptor Olev Männi ja arhitekt Ilmar Bork (Krivošejev 1960: 74; Kotšenovski 1991: 247).

Lenini monument kuulus nõukogude aja traditsiooniliste mälestusmärkide hulka. Arvati, et igas nõukogude linnas peaks tingimata asuma mälestusmärk "maailma proletariaadi juhile". Nõukogude Narvas püstitati erinevatel aastatel suisa viis Lenini monumenti. Esimene mälestusmärk (koopia Sergei Merkurovi tööst) oli massiivne betoonist skulptuur $(3,5 \mathrm{~m})$, mis püstitati madalale 
postamendile ning kujutas Leninit täispikkuses liikumisele viitavas asendis. Mälestusmärk avati 1952. aastal V. I. Lenini nimelisel väikesel haljasalal Kreenholmi manufaktuuri peakontori kõrval, see demonteeriti 1980. aastal (Bulatnikov 2012: 181). Teine Lenini monument (samuti koopia Sergei Merkurovi tööst) püstitati Pimeaia territooriumile (kandis toona Linnapargi nime) 1953. aastal (Bulatnikov 2012: 183). 1970. aastal püstitati Narva mööblivabriku territooriumile Lenini marmorbüst (autor: L. Mess) (Narva Muuseumi raamatukogu) seoses saja aasta möödumisega Lenini sünnist. Viimane (püstitamise järgi viies) kujutas endast skulptuurportreed Leninist. See Kalju Reiteli töö püstitati 1982. aastal Kreenholmi 125. aastapäevaks Kreenholmi läbikäidavasse hoovi Lenini prospekti esisele väljakule (Kotšenovski 1991: 275).

Meid huvitav Lenini mälestusmärk, mis arvati Narva pulmamarsruuti, oli püstitamisjärjekorras kolmas. See seati püsti linna Peetri keskväljakule ning kujutas pronksist Leninit täispikkuses. Selliste kujude traditsioonilisteks elementideks olid ülestõstetud suundanäitav käsi (ametlik retoorika tõlgendas seda žesti kui sümboolset viidet helge tuleviku suunas) ja sonimüts juhi riietuse atribuudina. Kuna soni sai olla kas ainult juhi peas või käes, siis käisid nõukogude ajal ringi anekdoodid, milles kasutati neid Lenini monumentide traditsioonilisi motiive. Räägiti kahe soniga Lenini monumendist - tähelepanematuse tõttu oli skulptor kujutanud soni Leninil nii peas kui ka käes. Narva Peetri väljaku Lenini kuju oli ilma sonita, kuid ülestõstetud käega. Narva linnafolklooris on seda motiivi korduvalt kasutatud. On teada mitmed pajatusi sellest, kuidas tõlgendada Lenini poosi. Ühes neist on tuntav iroonia nõukogude ideoloogia aadressil ja nõukogudeaegse tegelikkuse negatiivne hinnang:

LLG: V. I. Lenini kuju seisis väljakul, näitas: “Õiget teed pidi lähete, seltsi-

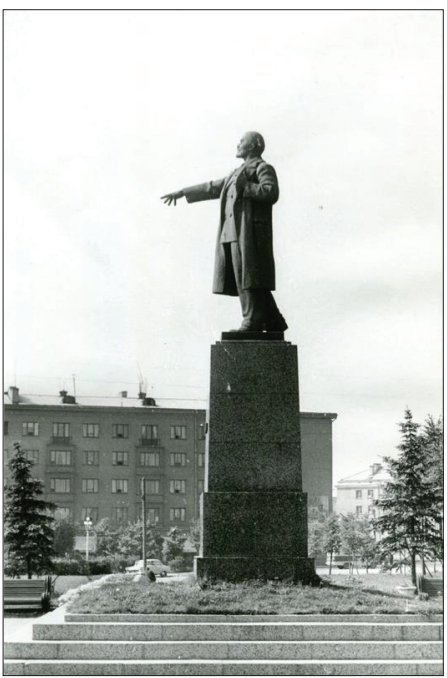
mehed! Kahju, et kohale ei jõudnud” (EN 11-66).

Foto 1. Olav Männi. V. I. Lenini monument Narvas, 1960-1975, EKM j 59395 FK 3021, Eesti Kunstimuuseum SA (http:/ / www.muis.ee/museaalview /3537452). 
Kuna nõukogude ajal näitas Lenin käega hoonete suunas, mis asusid väljaku vastaspoolel (partei linnakomitee ja hoiukassa hooned), siis sõltuvalt sellest, millise hoone poole Lenin rääkija meelest osutas, muutusid ka pajatuse sisu ja varjatud mõte.

MM: Peetri väljakul seisis vanasti V. I. Lenini kuju. Tehti nalja, et Lenin osutab alati hoiukassa suunas (EN 11-04).

OB: Lenin osutab hoiukassa suunas: "Raha pole, siis mine hoiukassasse" (EN 14-01).

AG: Lenini kuju osutas partei linnakomiteele: "Hoidke neil litsidel silma peal!" (EN 11-06).

Uus variant sellest pajatusest ilmus 1990. aastatel ning süžeele lisandus tualettruum, mis asus ja asub tänapäevani ühes Peetri väljaku hoonetest:

P: V. I. Lenini kuju seisis varem Peetri väljakul, osutas "Lennart Meri nimelise tualeti” suunas. Narvasse jõudnud president Meri läks sinna tualetti ning pärast seda tehti tualett ümber Euroopa moodi (EN 11-41).

On teada, et Lennart Meri käis presidendina mitmeid kordi Narvas: tema presidendiaja kodulehekülje andmetel toimusid ametlikud visiidid 1993, 1996, 1999, 2000 (VP). Kuid trükiallikad ei teata ühestki skandaalsest loost, mis oleks seotud presidendi külaskäiguga Narva Peetri väljakule. Siiski leidis Narva folklooris oma tõlgenduse lugu sellest, kuidas president L. Meri külastas Tallinna lennujaama tualetti. 1997. aastal pärast ametlikku visiiti Jaapanisse korraldas Eesti president teda oodanud ajakirjanikele pressikonverentsi demonstratiivselt tualetis, soovides sel moel osutada asutuse sobimatule olukorrale, mis lõi välismaa külalistele pildi Eestist. Seda lugu arutati laialdaselt Eesti meedias ning see kutsus esile ühiskondliku vastukaja (vt selle kohta: Kasela 1999; Postimees 2006). Pärast seda pressikonverentsi tehti Tallinna lennujaama tualetis tõepoolest (nagu siis nimetati) euroremont (vt Rozental 2010).

1993. aastal võtsid Eesti Vabariigi valitsus ja Narva linnavalitsus vastu otsuse demonteerida Lenini mälestusmärk ja viia see üle Narva kindluse territooriumile, mis leidiski aset sama aasta 21. detsembril (Bulatnikov 2012: 194). Pärast Narva muuseumi eksponaadiks saamist osutus mälestusmärk endise asupaigaga võrreldes 90 kraadi põhja suunas keeratuks (vt foto 2). Lenini osutav žest leidis uue sihi - Narva jõe põhjakallas (Venemaa). Pajatused mälestusmärgist hakkasid nüüd kõlama uut moodi ja Lenini žest omandas uusi tõlgendusi, mis peegeldavad linnaelanike mõtisklusi uue ajastu poliitiliste sündmuste kohta: 


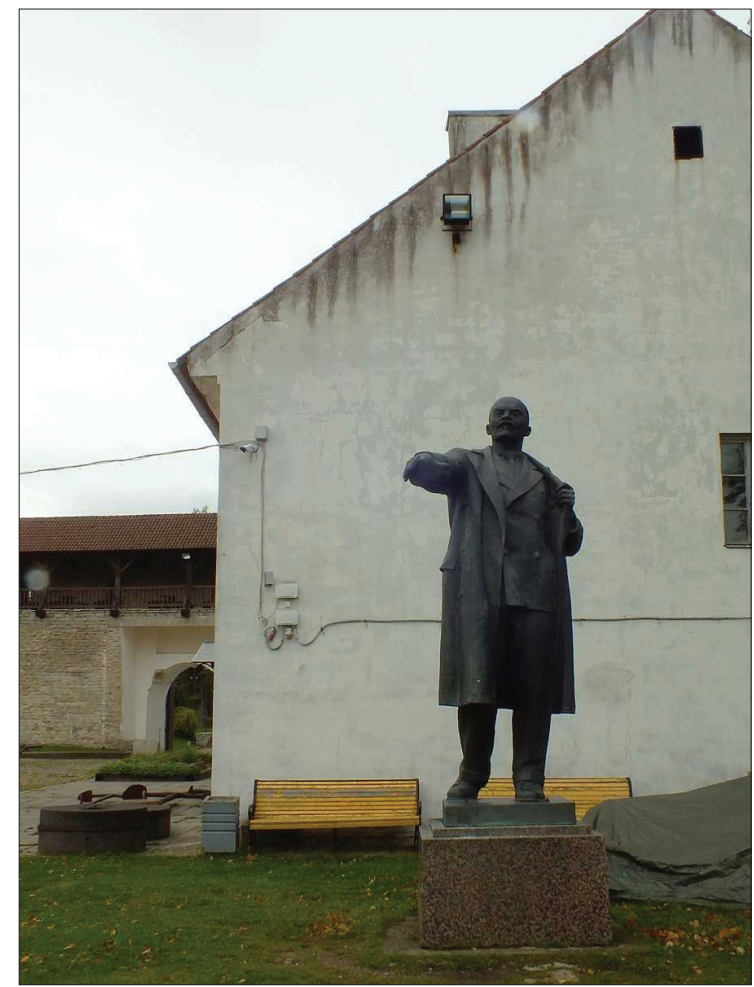

Foto 2. Lenini monument Narva kindluse territooriumil. Gleb Nechvolodovi foto.

PM: 1990ndatel räägiti, et Lenin näitab Venemaa suunas: "Raudteejaam Venemaa!” (venelastel on vaja sõita ära Eestist) (EN 11-12).

Teises pajatuses kõlavad motiivid enda kaitsmisest, mis on seotud omaenese elu hinnanguga Narvas (selgub, et pole soovitav, et Lenin osutaks teatud objektidele linna piires).

M2: Tähedab, et võeti Lenin ja pandi sinna, kus on praegu. Praegu seisab ta seljaga Narva poole, aga käega osutab üle jõe. Narva elab ainult paremini ja paremini (EN 11-29).

Nõukogude ajal oli Lenini monument Peetri väljakul ametlike pidulike ürituste osaliseks. Hiljem monumendi ette ehitatud tribüünidelt tervitasid linnaisad 1. mai paraadi, oktoobrirevolutsiooni miitingu ja võiduparaadi ajal linlasi. Lenini monument oli nii nõukogude Narva kui ka nõukogude epohhi sümboliks. 
See asus nõukoguliku Narva keskel, linna südames, linna administratiivhoonete ees. Pole juhuslik, et ühe nõukogude ajal välja antud Narva fotoalbumitest avab just selle mälestusmärgi foto, mis positsioneerib Narvat kui nõukogulikku linna (vt Migdal 1978).

On ilmne, et just neil põhjustel sai nõukogude ajal Lenini monumendist Peetri väljakul pulmasõidu objekt. On iseloomulik, et selle mälestusmärgi külastamisega kaasnes lillede rituaalne asetamine monumendi jalamile (see rituaal kordas traditsioonilisi tegevusi Lenini mälestusmärgi juures, mis olid kinnistunud ametlikus peokultuuris).

Kõrvaltegevusena toimus mälestusmärgi juures pulmaseltskonna pildistamine. Grupifotod Lenini mälestusmärgi juures olid lavastusliku iseloomuga: pruut ja peigmees olid esimese rea keskel trepi alumisel astmel. Nende pulmafotode kompositsioon oli lahendatud nõukogude grupifotode-portreede (kooli, ettevõtte, spordivõistkonna) traditsioonilises stiilis.

Lenini monumenti tajus noorpaar kui nõukogude identiteedi sümbolit. Selle kaasamine pulmakombestikku ühildus teadliku tsentraliseeritud tööga nõukoguliku pulmakombestiku loomisel: uue perekoodeksi juurutamine, komsomolipulmade traditsioonid, kihlasõrmuste traditsiooni taassünd, pruutkleidi "tagasitulemine" 1950. aastate teises pooles (Rostovskaja 2012), õnnepaleede ehitamine linnadesse (Timofejeva 2004: 106), abielu piduliku registreerimisprotseduuri loomine 1960. aastate keskel (Žirnova 1980: 83; Gromov 2012).

\section{Ringristmik}

Sõjaeelse põhilist linnastruktuuri ${ }^{5}$ säilitavate keskmagistraalide (Tallinna maantee, Puškini ja J. Anvelti (praegu P. Kerese) tänav) ristumispaika rajati 1965. aastal ringristmik, mida linnarahvas hakkas kutsuma Ringiks. See rahvapärane nimetus leiab peegeldust ka teaduslikus kirjanduses, nii saadab O. Kotšenovski raamatus "Narva. Linnaehituse areng ja arhitektuur" (Tallinn, 1991) ringristmiku fotot pealkiri "Koormuse vähendamise ring Puškini, Tallinna maantee ja J. Anvelti tänava ristumisel” (Kotšenovski 1991: 257). Liiklus Narva ringristmikul erineb liikumisest analoogilistel ringristmikutel teistes Eesti linnades: teistes kohtades on eesõigus sellel, kes liigub ringi pidi, Narva ristmikul saab aga eesõiguse auto, kes sõidab ringile Puškini tänavalt, sest ringile on Puškini tänava ühenduse eel paigutatud "Peatu ja anna teed" (STOP) märk. Ring arvati pulmamarsruuti nähtavasti 1960. aastate teisel poolel ja see on püsinud seal tänaseni (vt foto 3 ).

Meie vastajate ühe versiooni järgi sõidab pulmakorteež teel õnnepaleest Narva-Jõesuusse ringi kolm korda ${ }^{6}$ läbi, teavitades pulmast autosignaaliga. Vrd: 


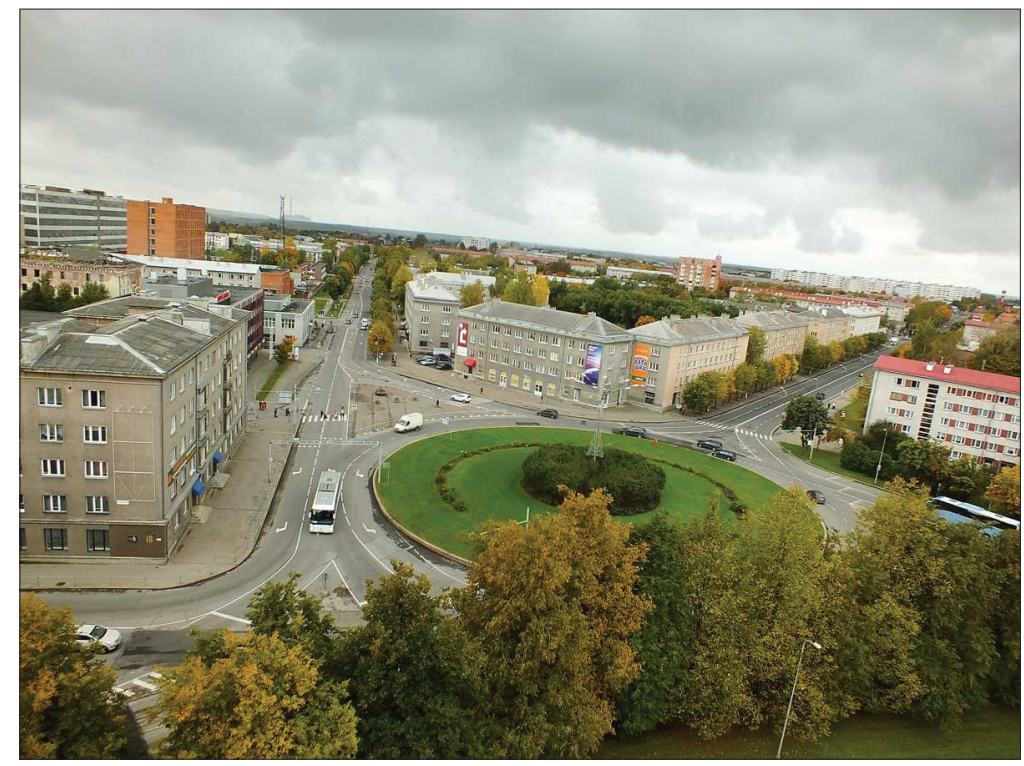

Foto 3. Ringristmik Narva keskmagistraalide (Tallinna maantee, Puškini ja P. Kerese tänava) ristumispaigal. Gleb Nechvolodovi foto.

OO: Ringi pidi! Ringi pidi kolm korda tiirutada [muheleb] Ja siis vot juba Narva-Jõesuusse...

I 11: Ja mida te siis tegite?

OO: Noh, kui sõitsime, siis andsime aina signaali. Ja meile anti vastu signaali.

I 12: See tähendab, et kolm korda?

OO: Jah, kolm korda mööda seda ringi. Kusjuures ma olen olnud viies pulmas, ja neis viies pulmas, vot neil kõik kolm korda mööda ringi sõidavadki. Üldiselt tehakse kolm ringi.

I 12: Kas see on kohustuslik?

OO: Noh, enam-vähem jah. Ei tea (EN 14-01).

Teise versiooni järgi: ühe-, kahe-, kolme-, ja enamakordne liikumine mööda ringi on pulmaprotsessioonis osalejate sümboolne "hea soov" noorele perele ühte, kahte või enamat last vastavalt saada. Vrd:

I 12: No ja siis istusite te autosse ja... kuhu sõitsite?

NZ: No, no, siis otse mööda Puškinit, ja siis oli meie ees... ring! Ja siis tuleb meil meelde, et ringil on vaja ringe keerutada. Ja näe ma mäletan, et sõitsime kaks ringi, mitte kolm. Keegi ärgitas kolme. Kaks ringi tegime ära... 


\section{11: Aga miks ainult kaks?}

NZ: Niipalju kui on ringe, niipalju soovitakse sulle tegelikult lapsi...

I 12: Kas tõesti?

NZ: Ja teises pulmas me näe... Vot, ma räägin pärast teisest pulmast...

Niipalju ringe nagu keerutad - niipalju lapsi soovid sellele perele (EN 14-04).

Osa narvalasi mõistab aga pulmaringide tegemise kombe hukka, pidades seda linnaelanike rahu rikkumiseks, liiklussegaduste tekitamiseks ning loobuvad sellest teadlikult.

Millegi ümber sõitmine või kõndimine on pulmakombestiku kohustuslik ja traditsiooniline element, mis esineb pruudikuulamisel, kosimisel, rituaalides, mida viiakse läbi pruudi kodus enne pruudipärja pähepanemist ja pulmarongi koostamise ajal, kiriklikus laulatuses ja rituaalides, mida sooritatakse pärast laulatust kodus (vt Žirnova 1980: 31-32, 43, 51, 53, 55). Veenev on Galina Žirnova arvamus, et nimetatud rituaalidel ei ole geneetilist seost 19. sajandi teise poole vene tavaga teha pulmarongiga tiir ümber linna. "See komme arenes linlastel seoses tseremoniaalse pulmarituaali osa tugevnemisega, mis pidi avalikult demonstreerima pere rikkust ja nimekust, ühe sotsiaalse kihi ülemust teise üle" (Žirnova 1980: 68). Samas iseloomustab millegi ümber kõndimine või sõitmine ja kolme sakralisatsioon ka pulmakäitumist rahva- ja õigeusklikus traditsioonis. Seega võib rääkida niisuguste elementide tüpoloogilistest siiretest mineviku pulmatavandist 20. sajandi pulmakombestikku.

20. sajandi lõpus ja 21. sajandi alguses taandub Narva pulmakombestikus sõit ümber linna sõiduks ringristmikul ning ümbersõit ise omandab lisaks demonstreerimisele uue sümboolse tähenduse.

1960. aastatel sai Ringist teine ja viimane linnaobjekt, mis pulmamarsruuti arvati. Vaatamisväärsuste külastamine osutus sisuliselt mitte sõiduks linnas, vaid sõiduks linnast välja. 1960. aastatel tähendas see sõitu Narva-Jõesuusse "Šiškini männi" juurde.

\section{"Šiškini mänd"}

"Šiškini mänd" on kolmas pulmamarsruuti lülitatud külastuskoht, ja see on oma tähenduse säilitanud tänaseni. Puu, mille ümbermõõt on $4,1 \mathrm{~m}$ ja kõrgus $19 \mathrm{~m}$, erineb välimuselt Läänemere ranniku mändidest. Selle asukoht on NarvaJõesuu kuurordi territooriumil Merekülasse suunduva maantee ääres ning puu on kohalik vaatamisväärsus (vt foto 4 ). 


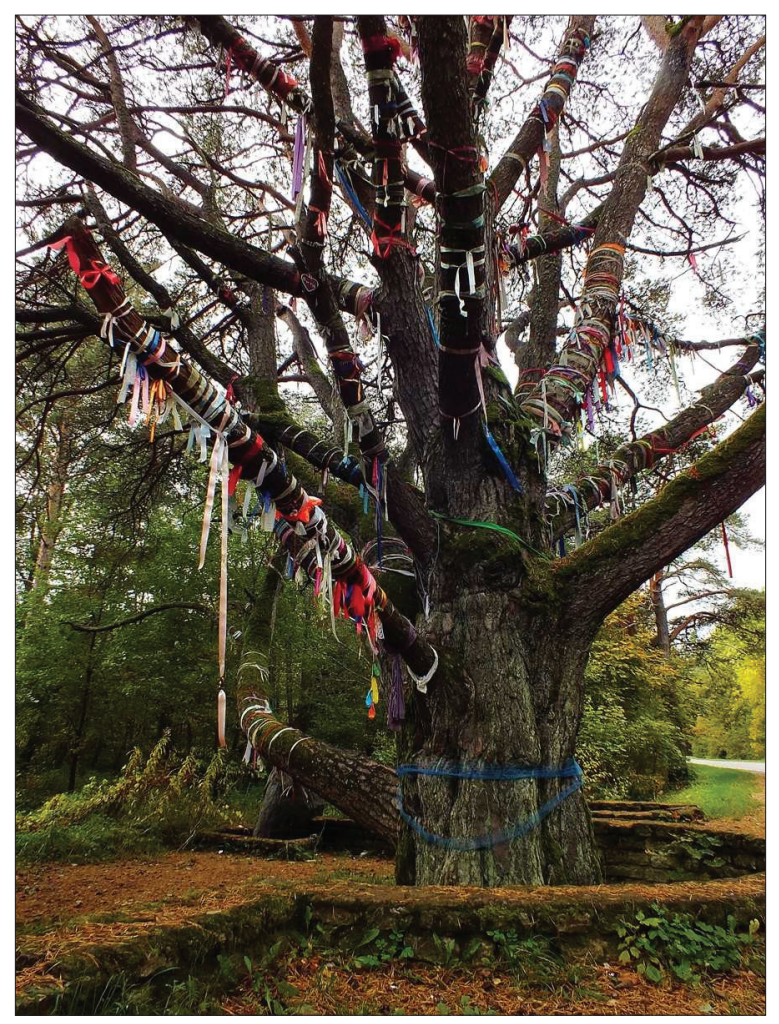

Foto 4. "Šiškini mänd” Narva-Jõesuu kuurordi territooriumil. Gleb Nechvolodovi foto.

Narvalased seostavad seda mändi 19. sajandi teise poole suure vene maastikumaalija Ivan Šiškiniga (1832-1898), kes aastail 1888, 1892, 1894 ja 1895 puhkas ja töötas Hungerburgis - tänases Narva-Jõesuus (Mazanov 2012; Mazanov 2014). Ühe versiooni järgi armastas kunstnik istuda võimsa puu all, joonistada ja välja mõtelda "uute piltide süžeesid" (Krivošejev 1968: 35), teise versiooni järgi, mis kerkib esile Narva elanike lugudes, sai mänd ise Šiškini loomingu objektiks.

Narvalaste mälestuste põhjal oli 1970. aastatel noorpaaridel kombeks kaunistada mändi siidlintidega: peigmees (nüüdsel ajal küll sagedamini pulmarituaali tunnistaja) ronis puu otsa ja sidus selle külge lindi. Kui uskuda Viktor Strelkovi tõendeid, on lintide sidumine männi külge ühe veel vanema traditsiooni taassünd. Nagu väidab uurija, oli armunutel kombeks ehtida mändi veel enne seda, kui seda hakati kutsuma "Šiškini männiks” (Strelkov 2007: 238). 
Toona uskusid noored armunud, et lindi sidumine toob kaasa peatsed pulmad (Žilkin 2004: 124; Strelkov 2011: 352).

Ühest küljest viitab see vanale eesti rahvakombele. Paganlikus kultuuris oli puu tihti muinaseestlaste austamise objekt. Arvati, et puu abil hoiab inimene kontakti vaimude maailmaga, jumalustega, kes kaitsesid teatud territooriumi asukaid (Viires 1975; Ariste 1977; Puss 1995; Eisen 1996 jt). Komme kaunistada ohvripuud lintidega on teada iidsetest aegadest; erinevates Eesti paikades on seniajani säilinud puud, mis funktsioneerivad ohvripuudena (Puss 1995; Kaasik 2007). Tõenäoliselt on "Šiškini mänd" olnud ja on kohalike elanike jaoks üks selline ohvripuu (Kõivupuu 2011: 112-113; Žilkin 2004: 125).

Teisest küljest meenutab komme ehtida lintidega mändi vene talupojaolustiku rituaalset tüdrukutepeo kommet kaunistada "ilu” (kuusekest, kuuseoksa) lintidega, millega kaasnes sümboolse „ilu“ edasiandmine peigmehele (Timofejeva 2004: 93-94). Komme kaunistada "ilu" tüdrukutepeol on fikseeritud 19. sajandi lõpus ja 20. sajandi alguses mitte ainult talupojaolustikus, vaid ka linnakultuuris (äärelinnade elanike ehk endiste talupoegade hulgas) (Žirnova 1980: 45). Komme kaunistada kuuseoksa-“ilu" lintidega oli levinud ka Peipsi järve läänekaldal elavate kohalike vanausuliste seas. Nagu märgib Galina Žirnova, oli “pulmapuu, mis sümboliseerib neitsilikku ilu, üks iseloomulikke elemente kesk-vene, lõuna-vene ja ukraina pulmades" (Žirnova 1980: 45). Otsest sidet sümbolpuu rituaalse kaunistamisega tüdrukutepeol ja pulmasõidu ajal külastatava "Šiškini männi" vahel ei ole, aga ühe rituaali mõjumine teisele on üsna võimalik ${ }^{7}$.

Pulmakomme - lintide sidumine männile - on seotud noore kaasa proovilepaneku rituaaliga. Selleks, et raske ülesandega hakkama saada, peab peigmees üles näitama julgust, sest vaja on ronida kõrgele puu otsa. Arvati, et mida kõrgemale on seotud lint, seda parem on edasine abielu (Žilkin 2004: 125). Vrd:

OO: Et umbes mida kõrgemale siduda lint, seda kindlamini, see suur et ... abielu on pikem, igavene ... (EN 14-01).

Kuid sugugi kõik noorpaarid ei pea proovile vastu - linlased räägivad traagilisest juhtumist, kus kõrgelt puuoksalt alla kukkunud peigmees hukkus:

OO: Ma ainult halba lugu.... No jah, jah, pulma ajal. Sealsamas kukkus surnuks. Peigmees ise nagu kukkus surnuks, sest ta ronis nii kõrgele, et justkui libises. Ja oli isegi nii, et taheti ära keelata, no ja riputada sellele puule midagi. Noja nüüd, kui on riputatud, siis kõik püüavad juba koos: “Jah... ära kaugele roni!” Ainult, noh, riputati sinna ja kuhugile kõrvale oksakesele, et kõrgele ei ronitaks (EN 14-01). 
Selle loo olemasolu, samuti ka teised lood ohu kohta, millesse noorpaarid võivad siin sattuda (“Šiškini mänd" asub kiirusepiiranguta maantee vahetus läheduses (Vikulov 2013)), kõnelevad männi sümboolsest tähendusest ja ka männist kui kohast, kus pannakse proovile perekonna tulevik.

Komme siduda linte puu külge on seotud ka viljakuse motiividega. Narvalased kinnitavad, et tähtis pole ainult kõrgus, kuhu lint seotakse, vaid ka selle värv ning sidumise viis: kui lint on seotud lehviga, siis võib oodata noorpaari peresse tüdrukut, kui sõlmega - siis poissi. Dmitri Gromovi väitel on viljakuse motiiv tihti seotud mitmesuguste pulmapäeva külastuskohtade nimekirja lülitatud looduslike objektidega (Gromov 2012).

1990.-2000. aastatel rituaalsete tegevuste repertuaar mitmekesistus. Juba nõukogude ajal tuntud vahuveini joomise rituaalile lisandus komme lüüa tühi või täis šampusepudel puruks vastu männi juures asuvat kivi (tõenäoliselt on siin metonüümiline seos kombega purustada nõusid õnne pärast). Kivi paigutati siia kohalike võimude ja looduskaitsjate algatusel (Kõivupuu 2011: 112). Väärib tähelepanu, et ka Eesti paganlikus traditsioonis ei ole harvad juhtumid, kui ohvrikivid või -puud olid kõrvuti, moodustades koos püha koha (Tvauri 1999; Kaasik 2007). Muidugi ei saa me väita, et muistsete eesti ohverdusrituaalide ja "Šiškini männiga" seotud 20. sajandi teise poole pulmakommete vahel oleks geneetiline järjepidevus. Siiski ei saa jätta pööramata tähelepanu sellele, et nii arhailises eesti kultuuris kui ka kaasaegses vene kultuuris on see puu seotud peresuhete ja tulevase perekonnaõnne "programmeerimisega".

Selle männi tähendusest eesti rahvakultuuris kirjutas 1968. a Jevgeni Krivošejev: "Sellel puul on veel ka teine nimi - "musumänd", mis eesti keeles tähendab mändi, mille juures suudeldakse. Rahvauskumuse järgi on nii, et noored inimesed, kes esimest korda suudlevad selle puu all, armastavad üksteist igavesti" (Krivošejev 1968: 35-36). Puu on selle uskumuse järgi imettegev koht, mille külastamine pidi hästi mõjuma noorte inimeste saatusele. See uskumus seondub pulmakommete sakraalsete hoiakutega ja seetõttu on õigustatud "Šiškini männi" valimine kohaks, mis sümboolselt programmeerib noorpaari pika ja õnneliku elu. Võimalik, et lugu vanast eesti uskumusest Narva-Jõesuu teejuhis 1960. aastate lõpust (just sellel perioodil sai nõukogude linnades alguse pulmapäeva külastuskohtades käimise traditsioon) võis saada täiendavaks tõukeks arvata mänd pulmapäeva külastuskohtade hulka.

"Šiškini mändi" kui kohalikku vaatamisväärsust tunnevad kõik linnaelanikud, olenemata sotsiaalsest kuuluvusest või vanusest. Narva õpetajad-koduloouurijad on teinud selle külastamise kooliekskursioonidele kohustuslikuks, kontrollitakse õpilaste teadmisi "Šiškini männi” kohta ja hoitakse sellega üleval ka selle koha kui Narva pulmasõidu osa kestmist. 


\section{Kokkuvõte}

1960. aastatel Narvas kujunes pulmasõidu suund - linnast äärelinna (NarvaJõesuu). Pulmamarsruudist valisime artiklis lähemaks kirjeldamiseks kolm punkti: Lenini monument Peetri väljakul, ringristmik kesklinnas ja "Šiškini mänd" Narva-Jõesuus. Esimese koha - Lenini monumendi - juurde jõudis perekonnaseisu osakonnast jalgsi, selle külastamine oli linlastele oma nõukoguliku identiteedi kinnitamise vahendiks. Autode levik lubas lisada pulmasõitu uusi kohti. Teise koha - ringristmiku - külastamine täitis noorpaari eneseesitluse funktsiooni ning oli (ja jääb) narvakate identiteedi kindlustamise vahendiks. "Šiškini mänd" kui pulmasõidu viimane punkt sidus sündivat nõukogulikku pulmatavandit vanema pulmakultuuriga. Narva pulmaringkäigu kaks viimast objekti hoiavad oma positsiooni ka tänapäevases pulmamarsruudis. Nende pulmahuviväärsuste ümber kujuneb kombestik ja kohalik folkloor.

\section{Kommentaarid}

1 Sergei Nekljudov juhib 1995. aastal tähelepanu olulistele muutustele, mis on toimunud linnafolkloori traditsioonilistes vormides ning soovitab kasutada kaasaegse linnafolkloori vormide spetsiifika tähistamiseks terminit "post-folkloor" (vt Nekljudov 1995). Hilisemates töödes täpsustab S. Nekljudov selle termini sisu: post-folklooriks nimetab ta mitmesuguseid "linnalegendide” žanre (kuulujutud, seletused, kõmu) (Nekljudov 2013b).

${ }^{2}$ Lilija Timofejeva arvates "jagunes pulmakombestik 19. sajandiks kolmeks tüübiks: ilmalik (aadellik), linna, küla (talupoeglik, rahvalik). Kõikidel neil tüüpidel on nii ühiseid kui ka erinevaid jooni" (Timofejeva 2004: 65).

3 Võžlivets või vežlivets - vene murrakutes nimetati selliselt nõida, kes pulma kaitses ning kes tihti esines ka pulmategevuse juhi rollis (Astahhina 2016: 441).

4 Tõsjatskii-pulmarongi esimene ametimees, selles rollis esinesid tavaliselt peigmehe ristiisa või onu (Ušakov 1940).

5 Vt(Kotšenovski 1991: 224-225) esimese (1945. a, arhitekt A. Soans, insener-ökonomist A. Šipko), teise (1948-1951, arhitekt O. Keppe, ökonomistid K. Sirkina ja G. Motorina), kolmanda (1956. a, arhitekt L. Pettai, ökonomist G. Veis) ja neljanda (1963-1964, arhitekt O. Keppe, ökonomistid V. Heinvere, M. Umre) Narva generaalplaanide skeeme ja kirjeldusi, mis muutusid vastavalt rahvaarvu suuruse perspektiivide kalkulatsioonide ja elamispinna üldiste hoiakute muutumisega (hoonestu tiheduse plaanid, linnamajade korruste arv jne), ent säilitasid muutumatult peamagistraalide suunad (Kotšenovski 1991: 224-225). Oleg Kotšenovski arvates “on see kaasaegse Narva linnaehitusliku omapära (ajalooliselt kujunenud magistraalide ja teede säilitamine - J. N., O. B.) seisukohalt väga oluline, kuna linna hoonestu on täiest uus" (Kotšenovski 1991: 224).

6 Arvul kolm, nagu ka mõnel muul paaritul numbril (5, 7, 9), oli linlaste kosjas ja pulmades teatud rituaalne tähendus ja neid loeti arvatavasti õnnetoovateks (Žirnova 1980: 38). 
7 Peame võimalikuks traditsioonilise vene talupojapulma mõju “Šiskini männi” juures kujunevale rituaalsete toimingutele. Lääne-Euroopa pulmatraditsioonide ja nn uue ajastu (new age) mõju peame aga vähetõenäoliseks. Oleks raske eeldada, et 1960. aastate nõukogude industriaalses provintsilinnas, mille elanikkond kujunes suures osas NSV Liidu küla- ja väikelinna ümberasukate juurdevoolu arvelt, võinuks hipide ja biitnike subkultuurid, esoteerilised liikumised või okultsed meeleolud kasvõi väiksemalgi määral kohalikku linnakultuuri mõjutada.

\section{Tsiteeritud vastajate nimekiri}

AG - mees, sündinud 1937. a (EN 11-06).

LLG - naine, 83aastane (EN 11-66).

M2 - mees, umbes 50aastane, sündis Tallinnas; Narvas on elanud umbes 15 aastat (EN 11-29).

MM - naine, sündinud 1987. a, üliõpilane (EN 11-04).

NZ - naine, sündinud 1974. a Narvas, kõrgharidus (EN 14-04).

NK - naine, sündinud 1966. a Kohtla-Järvel, kõrgharidus, Narvas elab 1969. aastast (EN 14-02).

OB - naine, sündinud 1974. a Narvas, kõrgharidus (EN 14-14).

OO - naine, sündinud 1987. a Narvas, rakenduslik keskharidus (EN 14-01).

P - mees, sündinud 1959. a Novgorodi oblastis, keskharidus, elanud Peterburis, Narvas elab 1979. aastast (EN 11-41).

RM - naine, sündinud 1940. a Valgevenes, 1954. aastast elas Ivangorodis, 1961. aastast elab Narvas (EN 11-12).

\section{Kogujad (uurijad)}

I 11 - Jelena Nõmm

I 12 - Olga Burdakova 


\section{Kirjandus}

Ariste, Paul 1977. Vadjalaste puu- ja metsakultusest. Etnograafiamuuseumi aastaraamat XXX. Tallinn: Valgus, lk 147-156.

Astahhina, Ljudmila 2016 = Astahhina, L. Ju. Problemy filologichsekoi dostovernosti istochnikov po russkoi istoricheskoi leksikologii. Dissertatsiia na soiskaniie uchenoi stepeni doktora filologicheskikh nauk. Moskva: Moskovskii pedagogicheskii gosudarstvennyi universitet.

Boitsova, Olga 2007 = Boitsova, O. Rol' fotografii v sovremennom gorodskom svadebnom obriade. Iarskaia-Smirnova, Elena \& Romanov, Pavel \& Krutkin, V. L. (toim). Vizual'naia antropologiia: novye vzgliady na sotsial'nuiu real'nost'. Saratov: Nauchnaia kniga, lk 78-101.

Bulatnikov, Vadim 2012. Nõukogude ajastu ausambad Narvas 1945-1960. Kriiska, Aivar \& Ivask, Merike (toim). Märgilised mälestised. Uurimisi Narva piirkonna ajaloost. Narva Muuseumi toimetised 12. Narva: Narva Muuseum, lk 168-200.

Eisen, Matthias Johann 1996. Tedre, Ülo (toim). Esivanemate ohverdamised. Tallinn: Mats.

Gromov, Dmitri 2012 = Gromov, D. V. Novye obriady sovremennogo brakosochetaniia . Kak razvivalas' traditsiia poseshcheniia "svadebnykh dostoprimechatel'nostei"? PostNauka. 15.10.2012 (http://postnauka.ru/longreads/2649 - 1. veebruar 2019).

Boode, Katrin (toim) 2004. Hõissa pulmad. Tallinn: Hansaärigrupp.

Kaasik, Ahto 2007. Ajaloolised looduslikud pühapaigad - väärtused looduse ja kultuuri piirimail. Valk, Heiki \& Kaasik, Ahto (koost). Opetatud Eesti Seltsi Toimetised 36. Looduslikud pühapaigad: väärtused ja kaitse. Tartu: Maavalla Koda, Tartu Ülikool, Õpetatud Eesti Selts, lk 23-74.

Kalits, Vilve 1981 = Kalits, V. Ia. O razvitii novyh svadebnyh traditsii v Estonskoi SSR. Kryvelev, Iosif \& Kogan, D. M. (toim). Traditsionnyie i novyie obriady v bytu narodov SSSR. Moskva: Nauka, lk 107-117.

Kalits, Vilve 1988. Eesti pulmad: traditsioon ja nü̈̈disaeg. Tallinn: Eesti Raamat.

Kasela, Argo 1999. Lennujaam avas uksed. Eesti Päevaleht 14.12.1999 (http://epl.delfi. ee/news/eesti/lennujaam-avas-uksed.d?id=50817219 - 6. veebruar 2019).

Kaunilt 1965 = Oja, Kalju (koost). Kaunilt, meeldejäävalt. Nõukogulikke kombetalitusi . Artiklikogumik. Tallinn: Eesti Raamat.

Kotšenovski, Oleg 1991 = Kochenovskii, O. Narva. Gradostroitel'noe razvitie $i$ arkhitektura. Tallinn: Valgus.

Krivošejev, Jevgeni (koost) 1960. Narva ekskursioonijuht. Tallinn: Eesti Riiklik Kirjastus.

Krivošejev, Jevgeni 1968 = Krivosheiev, Ie. P. Kurort Narva-Iyesuu. Tallinn: Eesti Raamat.

Kuzmina, Olga 2010 = Kuz'mina, O. V. Gorodskaia svadebnaia obriadnost' russkikh: Uchebnoie posobie. Kemerovo: KemGUKI. 
Kõivupuu, Marju 2011. 101 Eesti pühapaika. Tallinn: Varrak.

Mazanov, Juri 2012 = Mazanov, Iu. Shishkin i Narvskoie vzmor'ie. Mazanov, Iu. “Nyneshnee leto my zhili za Narvoi...”. Sankt-Peterburg: Renome, lk 9-38.

Mazanov, Juri 2014 = Mazanov, Iu. I. I. Shishkin na Narvskom vzmor'e. Sankt-Peterburg: Renome.

Migdal, Samuil 1978. Narva. Tallinn: Eesti Raamat.

Määrus 1964 = Stat'ia 22. O vnedrenii v byt sovetskih liudei novyh grazhdanskih obriadov. Sobraniie postanovlenii pravitel'stva Rossiskoi Sovetskoi Federativnoi Sotsialisticheskoi Respubliki 3. Moskva: Iuridicheskaia literatura, lk 41-45.

Narva Muuseumi raamatukogu = Istoricheskie pamiatniki, pamiatnye znaki... (Narva i Narva-Iyesuu). Naimenovanie pamiatnika istorii: Biust V. I. Lenina. Narva Muuseumi raamatukogu arhiiv.

Nekljudov, Sergei 1995 = Nekliudov, S. Posle fol'klora. Živaia starina 1. lk 2-4 (http:// www.folkcentr.ru/zhivaya-starina-1995-1/ - 7. veebruar 2019).

Nekljudov, Sergei 2013a = Nekliudov, Sergei. Chem postfol'klor otlichaetsia ot massovoi kul'tury? Postfol'klor. Kurs: Vvedenie v teoreticheskuiu fol'kloristiku. Postnauka (http:// postnauka.ru/video/9435 - 7. veebruar 2019).

Nekljudov, Sergei 2013b = Nekliudov, S. Postfol'klor v gorodskih traditsiiah XX veka. Postnauka (http://postnauka.ru/lectures/24463 - 7. veebruar 2019).

Nõuandeid 1959 = Nõuandeid ilmalike kombetalituste kohta . Tartu: Tartu Linna TSN Täitevkomitee kultuuriosakond.

Pm 2006 = Lennart Meri kui Üllataja. Postimees. 15.03.2006 (http://www.postimees. ee/1533365/lennart-meri-kui-ullataja - 31. jaanuar 2019).

Puss, Fred 1995. Puudega seotud pärimused ja traditsioonid Eesti rahvakultuuris. Proseminaritöö. Tartu: TÜ ajaloo osakonna etnoloogia õppetool. Käsikiri Eesti Kirjandusmuuseumis.

Puškarjova \& Šmeljova 1959 = Pushakariova, L. A. \& Shmeliova, M. N. Sovremennaia russkaia krest'ianskaia svad'ba (po materialam ekspeditsii v Kaliningradskuiu oblast' v 1956-1958 gg.). Sovetskaia etnografiia 3, lk 47-56.

Rabinovitš, Mikhail 1978 = Rabinovich, M. G. Svad'ba v russkom gorode XVI v. Chistov, Kiril \& Bernshtam, Tatiana (toim). Russkii narodnyi svadebnyi obriad: Issledovaniia i materialy. Leningrad: Nauka, lk 7-31 (https://www.booksite.ru/fulltext/chistov/text. pdf - 7. veebruar 2019).

Rostovskaja, Natalia 2012 = Rostovskaia, N. A. Evoliutsiia svadebnoi obriadnosti russkogo gorodskogo naseleniia Rossii v sovetskii period. Izvestiia Penzenskogo gosudarstvennogo universiteta im. V. G. Belinskogo. Gumanitarnyie nauki 27, lk 950-953.

Rozental, Väinu 2010. 8 aastat tagasi tegi Neiveltile maksuamet ettekirjutuse. Äripäev. 26.03.2010 (https://www.raamatupidaja.ee/uudised/2010/03/26/8-aastat-tagasi-tegineiveltile-maksuamet-ettekirjutuse - 27. veebruar 2019). 
Smolkin-Rotrak, Viktoria 2012 = Smolkin-Rotrak, V. Problema “obyknovennoi" sovetskoi smerti: material'noe i duhovnoe v ateisticheskoi kosmologii. Gosudarstvo, Religiia, Tserkov' v Rossii $i$ za Rubezhom 3-4 (30), lk 430-463 (http://www.religion.ranepa. $\mathrm{ru} / \mathrm{q}=\mathrm{ru} /$ node/287 -7 . veebruar 2019).

Strelkov, Viktor 2007 = Strelkov, V. Zolotoe kol'tso Gungerburga. Kurort Narva-Iyesuu. Sankt-Peterburg: Sotis.

Strelkov, Viktor 2011 = Strelkov, V. "Shishkinskaia sosna". Strelkov, V. Po zolotomu kol'tsu Gungerburga. Entsiklopediia dachnoi zhizni. Tallinn: Argo, lk 352.

Žilkin, Vladimir 2004 = Zhilkin,V. A. Shishkinskaia sosna. Prekrasnoe vedet nas cherez vse mosty: Sbornik statei, posviashchennyi russko-estonskim fol'klornym sviaziam. Izvara: Muzei-usad'ba N. K. Rerikha, lk 120-126.

Žirnova, Galina 1980 = Zhirnova, G. V. Brak i svad'ba russkikh gorozhan v proshlom i nastoiashchem. Moskva: Nauka.

Tedre, Ülo 1973. Eesti pulmad: lühiülevaade muistsetest kosja- ja pulmakommetest. Tallinn: Eesti Raamat.

Timofejeva, Lilija 2004 = Timofeieva, Liliia V. Traditsii i novatsii $v$ russkom svadebnom obriade. Dissertatsiia na soiskanie uchenoi stepeni kandidata filosofskikh nauk. Moskva: Moskovskii gosudarstvennyi universitet servisa (http://www.dissercat.com/content/ traditsii-i-novatsii-v-russkom-svadebnom-obryade - 7. veebruar 2019).

Toomistu, Aivo 2005. Eesti pulmad 20. /21. sajandi vahetusel. Tartu: Tartu Ülikool.

Tšistov, Kirill \& Bernštam, Tatjana 1978 = Chistov, Kiril \& Bernshtam, Tatiana (toim). Russkii narodnyi svadebnyi obriad: issledovaniia i materialy. Leningrad: Nauka (https:// www.booksite.ru/fulltext/chistov/text.pdf - 7. veebruar 2019).

Tvauri, Andres 1999. Eesti ohvrikivid. Mäetagused 11, lk 35-57 (doi:10.7592/MT1999.11. kivi).

Tähistagem 1960 = Tähistagem pidulikult perekondlikke sündmusi . Tallinn: Eesti Riiklik Kirjastus.

Ušakov, Dmitri 1940 = Ušakov, D. N. Tolkovyi slovar russkogo iazyka 4. Moskva: Gosudarstvennoe izdatelstvo inostrannyh i natsionalnyh slovarei.

Viires, Ants 1975. Puud ja inimesed. Puude osast eesti rahvuskultuuris. Tallinn: Valgus. Vikulov, Roman 2013 = Vikulov, R. U Shishkinskoi sosny v Narva-Iyesuu edva ne proizoshla tragediia. Viru Prospekt. 22.07.2013.

VP = Sisevisiidid. Ametlikud teated. Eesti Vabariigi President 1992-2001. Kodulehekülg (https://vp1992-2001.president.ee/est/ateated/Sisevisiidid.asp - 11. veebruar 2019). 
Summary

\section{Narva wedding sights: The beginnings of the wedding walk tradition}

\section{Jelena Nõmm}

Lecturer of Russian Culture at Narva College of the University of Tartu

Jelena.Nomm@ut.ee

\section{Olga Burdakova}

Associate Professor of Russian Language at Narva College of the University of Tartu Olga.Burdakova@ut.ee

Keywords: post-folklore, Russian wedding rituals, Narva wedding walk, wedding sights

The present article analyses a wedding walk as a constant element of the modern Russian wedding ritual in the post-Soviet cultural room. The article provides an insight into the history of the establishment of this ceremonial tradition, presents different research versions of the development of the Soviet tradition of newlyweds and guests' visiting of the wedding sights on the day of the wedding. The objects of Narva wedding train route are in the focus of attention; the formation of this route dates back to the 1960s. During this period the direction of the route of the wedding walk was determined - from the city to the suburb (Narva-Jõesuu). The map of the wedding train route had three destinations: the monument to Lenin in Peter's Square, the roundabout "Ring" in the city centre and Shishkin's Pine in Narva-Jõesuu. The last two of the above-listed objects are still holding their positions on the map of the modern wedding train route as well. The ceremonial culture and the local mythology are developing around these wedding sights. 